\title{
Glacier-Induced Alluvial Fan Development on the Northeast Tibetan Plateau Since the Late Pleistocene
}

OPEN ACCESS

Edited by:

Feng Cheng,

University of Nevada, United States

Reviewed by:

Xingqi Liu,

Capital Normal University, China

Weiming Liu,

Institute of Mountain Hazards and

Environment(CAS), China

*Correspondence:

Fuyuan An

dongzhu8@sina.com

Shanlu Li

qhnz@163.com

Specialty section:

This article was submitted to

Quaternary Science, Geomorphology

and Paleoenvironment,

a section of the journal

Frontiers in Earth Science

Received: 29 April 2021

Accepted: 23 June 2021

Published: 27 July 2021

Citation:

An F, BadingQiuying, Li S, Gao $D$,

Chen $T$, Cong $L$, Zhang $J$ and Cheng $X$

(2021) Glacier-Induced Alluvial Fan

Development on the Northeast Tibetan

Plateau Since the Late Pleistocene.

Front. Earth Sci. 9:702340.

doi: 10.3389/feart.2021.702340

\author{
Fuyuan $\mathrm{An}^{1,2,3 *}$, BadingQiuying ${ }^{1,2,3}$, Shanlu $\mathrm{Li}^{4 *}$, Donglin Gao ${ }^{5}$, Tianyuan Chen ${ }^{5}$, Lu Cong ${ }^{5}$, \\ Jinhu Zhang ${ }^{1,2,3}$ and Xiali Cheng ${ }^{1}$
}

${ }^{1}$ Key Laboratory of Physical Geography and Environmental Processes of Qinghai Province, School of Geographical Science, Qinghai Normal University, Xining, China, ${ }^{2}$ Key Laboratory of Tibetan Plateau Land Surface Processes and Ecological Conservation (Ministry of Education), Xining, China, ${ }^{3}$ Academy of Plateau Science and Sustainability, Qinghai Normal University, Xining, China, ${ }^{4}$ Qinghai Branch of China National Geological Exploration Center of Building Materials Industry, Xining, China, ${ }^{5}$ Key Laboratory of Comprehensive and Highly Efficient Utilization of Salt Lake Resources, Qinghai Institute of Salt Lakes, Chinese Academy of Sciences, Xining, China

The origin of alluvial fans at the drainage basin or the margins of the arid sedimentary basin on the northeastern Tibetan Plateau (NETP) has been a focus of debate among scientific communities. Extensive alluvial fans had developed in the mountain-basin systems of this region during the late Pleistocene. Based on geomorphic/stratigraphic studies and the optically stimulated luminescence (OSL) chronology, we investigated numerous alluvial sequences in the drainage basin of the coupled mountain-basin system on the NETP. Sedimentologic analyses showed that these alluvial sediments mainly comprise crudely meter and decimeter beds of fanglomerate and sandy lenticles, which occasionally contain boulders in the thinner layers. OSL dating results showed that the alluvial sediments were mainly developed during the late MIS 5, MIS 3, and Last Glaciation and Deglaciation (maximum aggradations), while little had occurred during the early Holocene. Comparing our ages and their probability density curves with those of glacial advances from the northeastern/eastern TP, the consistency of both records during different stages since the late Pleistocene suggested that the development of alluvial fans was driven by glacier activities, which yielded abundant outwash, feeding alluvial aggradations. Based on this finding, together with results of previous studies, we argued that the dynamics of alluvial geomorphic processes had a paleoclimatic origin rather than surface uplifts. Further studies indicated that the precipitation of glaciations originated from the ISM northward intrusion during the late MIS 5, MIS 3, and Holocene; however, it was mainly influenced by the westerlies during the Last Glaciation and Deglaciation. Therefore, the development of alluvial fans on the NETP represents coupling signals of the ISM and the westerlies on the interglacial-glacial cycle timescales. The coupling evolution of glacier activities and alluvial aggradations in the drainage basins of mountain-basin systems on the NETP provides a model for assessing the linkages between regional geomorphic processes and atmospheric circulations on hemispheric scales.

Keywords: alluvial fans, optically stimulated luminescence dating, glacier activities, moisture source, Northeastern Tibetan Plateau 


\section{INTRODUCTION}

Geomorphic processes in the drainage basins of river catchments offer insight into the response of mountain-basin surface dynamics to paleoclimate fluctuations (Owen et al., 2006; Chen et al., 2011; An et al., 2018a; Lehmkuhl et al., 2018; Li et al., 2020a; Tao et al., 2020). Using geomorphic processes to reconstruct paleoclimate changes often focuses on specific sedimentary or geomorphological archives such as fluvial terraces, eolian sediments, glacial landforms, lake shorelines, and alluvial fans (An et al., 2021). Geomorphic processes on the Northeastern Tibetan Plateau (NETP) have been intensively studied in recent decades due to its typical location of mountainbasin coupling and the interactional zone of diversiform atmospheric circulations (Owen et al., 2006; Wang et al., 2009; Chang et al., 2017; Stauch et al., 2017; An et al., 2018a, 2018b; Liu et al., 2019; Li et al., 2020b; Tao et al., 2020). For example, Owen et al. (2006) carried out systemic investigations on the alluvial fans, river terraces, and moraines along the eastern Kunlun Mountain slopes that indicated links between climatic amelioration, deglaciation, lake desiccation, and terraced alluvial fan evolution. Wang et al. (2009) likewise carried out an extensive optically stimulated luminescence (OSL) study of alluvial valley fills and associated terraces along the Kunlun Mountains and found synchronous aggradations in different rivers during the last glacial stage.

Similar to geomorphic units in the drainage basin, an alluvial fan is an important dynamic landform process, which commonly develops in areas of high topographic relief, especially in the transition zone between mountain-basin systems (An et al., 2018a). An alluvial fan is a cone-shaped deposit of silt, sand, and gravel that accumulates where a stream flows from an eroding upland catchment and debouches into an adjacent basin (Zhang et al., 2014). Alluvial fans trap sediment delivered from mountain source areas and exert an important control on the delivery of sediment to downstream environments, to axial drainages, and to arid sedimentary basins, and they preserve a sensitive record of environmental fluctuations within the high mountain source area (Ashworth, 2006). Alluvial processes are mainly influenced by tectonic activity, climate changes, and base-level controls. The understanding of such processes has progressed considerably in the past few decades (Owen et al., 2003, 2006; Zhang et al., 2011; An et al., 2018a), whereas effects of climate factors appear to exert an overwhelming control on late Quaternary sequences and sedimentary styles, especially in arid drainage basins (Gao et al., 2018). Alluvial sediments are sensitive to changes in orographic glacial activities and drainage hydrological conditions. They provide valuable information on paleoclimatic fluctuations of upstream areas (Ritter et al., 1995; Vandenberghe, 1995; Bridgland, 2010). Likewise, an alluvial fan is a medium of sediment transportation and groundwater discharge. For instance, high sediment supply to an alluvial fan resulted in the temporary blocking of the river channel and influenced the lake level of the adjacent Heihai Lake. This geomorphic process presumably occurred during or shortly after large glaciations (Stauch et al., 2017). The groundwater in the Qilian Mountains was recharged by high piedmonts, flowed through the alluvial fans from south to north, and was finally discharged several decades later from springs located along the toe of the fan (Guo et al., 2017). Recent studies have found that glacier advance was a key factor for the development of alluvial fans due to the abundant detritus production at the piedmont belt in the eastern Kunlun Mountains (Owen et al., 2006; An et al., 2018b; Cui et al., 2020). These researchers argued that the alluvial Sanchahe Formation filled in the Golmud River valley, described as "a set of periglacial fanglomerates," originated from the piedmont outwash yielded in the high Kunlun Mountains (Van Der Woerd et al., 2002). Therefore, it is important to investigate the association between glacial activities, alluvial fan developments, and atmospheric circulation changes on the orbital timescale of the late Quaternary and the spatial scale of the entire drainage basin of the NETP, through extensive geomorphic investigations and abundant chronology controls. If tectonic uplift were negligible for the formation of alluvial fans since the late Pleistocene, studying the climatic driving mechanism for the geomorphic process from the periglacial zone to the drainage basin would help us come up with a hypothesis that drainage alluvial geomorphic processes respond to climatic systems, moisture transportation, and orographic glacial activity on a hemispheric scale.

In this study, we conducted a geomorphologic and stratigraphic investigation using 59 OSL dating ages from a series of alluvial fans in widespread drainage basins on the NETP. The aims of our study included the following: (i) to establish a chronological framework of these alluvial fans since the last interglaciation, (ii) to establish links between the orographic glacial activity and alluvial geomorphic development, and (iii) to explore their paleoclimatic implication on the atmospheric circulation scale.

\section{SAMPLE COLLECTION AND METHODS}

\section{Study Area and Environmental Parameters}

The Northeastern TP, with a series of high mountains, basins, alpine steppes, and deep-cutting gorges, covers an area of $\sim 580,000 \mathrm{~km}^{2}$ (Bureau of Geology and Mineral Resources of Qinghai Province, 1991). The extensively developed basinmountain systems are the distinguishing topographical feature in this region (Kapp et al., 2011; Liu et al., 2015; An et al., 2018b). The diastrophism in this region shows large-scale crustal shortening and strike-slip faults during the late Cenozoic (Yuan et al., 2011). These faults bring up westnorthwest-oriented orogenic belts, such as the Kunlun Mountains, the Qilian Mountains, Ela Mountain, and Riyue Mountain, which separate the several large Cenozoic basins including the Qaidam, Gonghe, Qinghai Lake, and Xining basins (Figure 1) (Yuan et al., 2011; Zhang et al., 2014). The alluvial fans associated with strong orographic weathering developed on the piedmonts along both sides of these high mountains. These alluvial fans are almost continuous within the tributary valleys and eventually join with the main valley fill that stretches along the margins of the basins (Owen et al., 


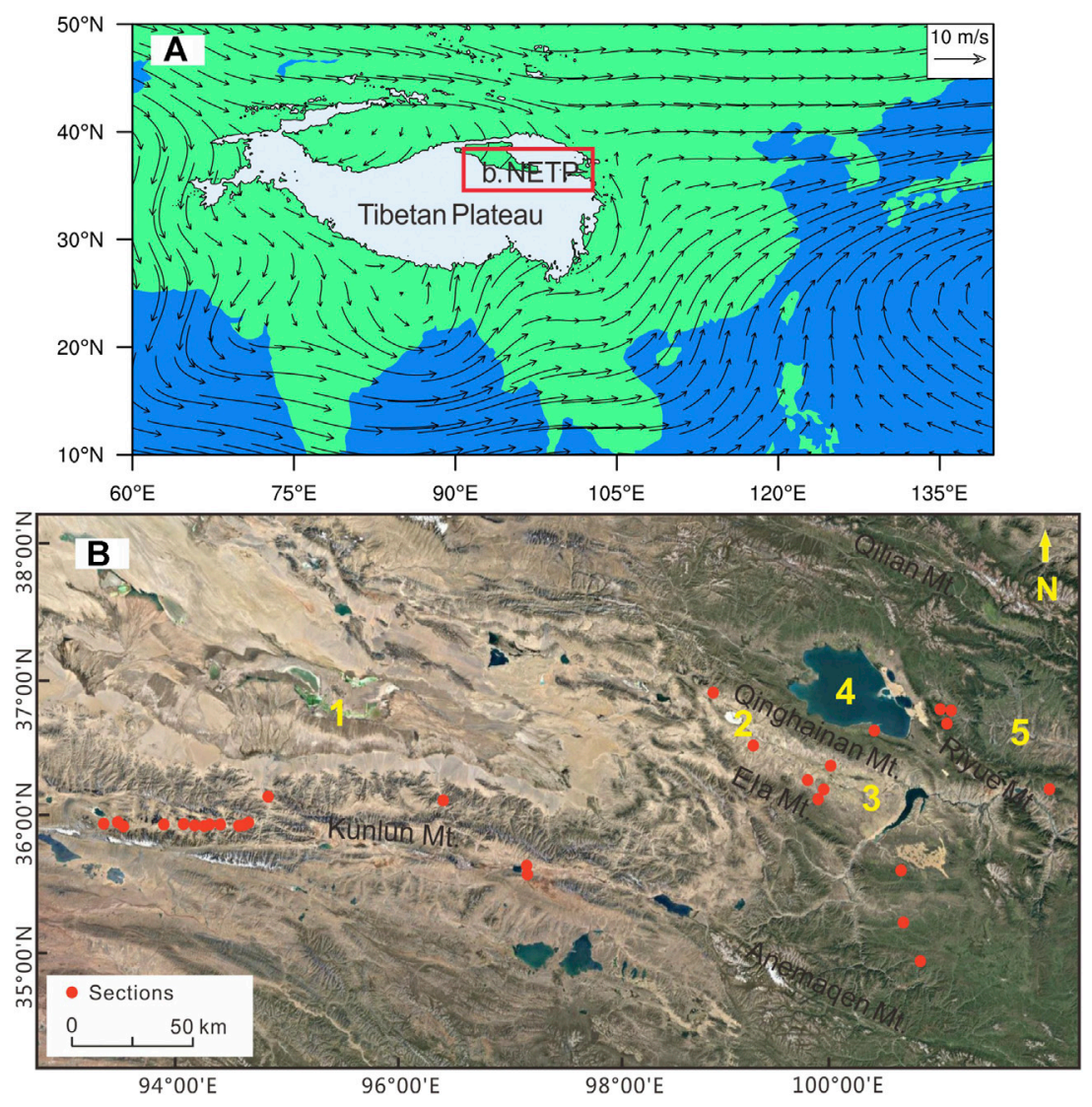

FIGURE 1 | Location map showing the study area and study sections. (A) Average atmospheric flow fields at the $700 \mathrm{hPa}$ isobar in summer (modified from Li et al., 2020); the red square denotes the location of the study area. (B) Enlargement showing the Northeastern Tibetan Plateau (NETP) and the main mountain-basin systems in this region (1. Qaidam Basin; 2. Chaka Basin; 3. Gonghe Basin; 4. Qinghai Lake Basin; and 5. Xining Basin).

2006; An et al., 2018b; Gao et al., 2018). In the southern margin of the Qaidam Basin, the alluvial landforms contain three subgeomorphic units: the piedmont alluvial fans along the slopes of the Kunlun Mountains, the main valley fill in the drainages, and the distal alluvial delta fan that cascades into the basin (An et al., 2018b). The highly dissected alluvial fans stretch out to the river valleys, and these are many tens of meters of alluvial fans that form the main valley fill. In the vicinity of the oasis preceding the mountain, a typical valley alluvial fan radiating from a series of large tributary valleys coalesces with the alluvial fill of the main drainage and then drains into the salt lakes in the Qaidam Basin and forms the distal alluvial delta fan (Owen et al., 2006). Five strath terraces have been developed within the alluvial fill (i.e., the Sanchahe Formation) in the middle reaches of the Golmud River, forming the spectacular fluvial landform. The Chaka Basin is part of the Gonghe Basin in the northeastern part of the TP, and it is separated from the Qaidam Basin by Ela Mountain (Liu et al., 2008). The basin is adjacent to the Qinghai Lake basin to the north by the Qinghainan Mountains (Zhang et al., 2012). The alluvial fans in the Chaka-Gonghe-Qinghai Lake regions are divided into three independent landform units, which include the north of the Ela Shan and both sides of the piedmonts of the Qinghainan Mountains. The northern alluvial fans in the
Chaka-Gonghe Basin are characterized by bigger area and short lengths, but the southern Qinghai Lake area is relatively small (Zhang et al., 2014). The alluvial fans in the mountains of the eastern Qinghai Lake basin basically cascade from the lateral tributary valleys and stretch out to the main river drainage basin. These fans usually extend $10-20 \mathrm{~km}$ to form cliff terraces $30-65 \mathrm{~m}$ above the riverbed, and they likewise become detrital aggradations and valley fill (Guo et al., 2017; Liu et al., 2017; Li et al., 2018). Therefore, a large number of alluvial fans constitute the most impressive geomorphic processes in the mountain-basin systems of the NETP. These alluvial fans provide the ideal materials to study paleoclimatic/tectonic history in this region. Although earthquakes occur frequently in the region and the average strike-slip rate of the Kunlun-Qinling Fault in the Quaternary was up to $\sim 10 \mathrm{~mm} / \mathrm{y}$ (Van Der Woerd et al., 2002; Li et al., 2005), no indicators of tectonic uplift activity during the late Pleistocene, such as mole tracks, have been observed in the Golmud catchment (Li et al., 2005; Wang et al., 2009; Stauch et al., 2017).

The elevations of the sampling sites range from 2,700 to $4,200 \mathrm{~m}$ a.s.l. These elevation gradients present a trend of high in the west and low in the east. The drainage basins of the Kunlun and Qilian Mountains have the average elevations of $\sim 4,000 \mathrm{~m}$ 
TABLE 1 | OSL sample information and dating results of the alluvial sections.

\begin{tabular}{|c|c|c|c|c|c|c|c|c|c|c|c|}
\hline $\begin{array}{l}\text { Sample } \\
\text { no. }\end{array}$ & Coordinate & $\begin{array}{l}\text { Profile } \\
\text { top } \\
\text { elevation } \\
\text { ( } m \text { a.s.I.) }\end{array}$ & $\begin{array}{l}\text { Depth } \\
\text { (m) }\end{array}$ & $\begin{array}{c}\text { Grain } \\
\text { size } \\
\text { range } \\
(\mu \mathrm{m})\end{array}$ & K (\%) & Th (ppm) & U (ppm) & $\begin{array}{l}\text { Water } \\
\text { content } \\
(\%)\end{array}$ & $\begin{array}{l}\text { Dose } \\
\text { rate } \\
\text { (Gy/ka) }\end{array}$ & $\begin{array}{l}D_{e} \\
\text { (Gy) }\end{array}$ & $\begin{array}{l}\text { OSL age } \\
\text { (ka) }\end{array}$ \\
\hline HF4-1 & $\begin{array}{l}35^{\circ} 52^{\prime} 57.14 " \mathrm{~N} \\
93^{\circ} 30^{\prime} 55.911 \mathrm{E}\end{array}$ & 4287 & 3.10 & $38-63$ & $2.42 \pm 0.10$ & $9.29 \pm 0.27$ & $1.73 \pm 0.06$ & $15 \pm 5$ & $3.12 \pm 0.21$ & $50.4 \pm 0.84$ & $17.2 \pm 1.1$ \\
\hline HF8-2 & $\begin{array}{l}35^{\circ} 51^{\prime} 55.82^{\prime \prime N} \mathrm{~N} \\
94^{\circ} 12^{\prime} 26.12^{\prime \prime} \mathrm{E}\end{array}$ & 3810 & 11.0 & $38-63$ & $1.61 \pm 0.05$ & $10.5 \pm 0.29$ & $2.32 \pm 0.09$ & $15 \pm 5$ & $2.72 \pm 0.19$ & $34.7 \pm 0.9$ & $12.8 \pm 1.0$ \\
\hline HF8-4 & $\begin{array}{l}36^{\circ} 56^{\prime} 25.82^{\prime \prime N} \\
93^{\circ} 12^{\prime} 33.20^{\prime \prime} \mathrm{E}\end{array}$ & 3946 & 23.0 & $38-63$ & $1.60 \pm 0.05$ & $9.42 \pm 0.27$ & $1.94 \pm 0.08$ & $10 \pm 5$ & $2.66 \pm 0.20$ & $130.4 \pm 2.9$ & $49.0 \pm 3.8$ \\
\hline HF17-1 & $\begin{array}{l}35^{\circ} 52^{\prime} 11.01^{\prime \prime N} \\
94^{\circ} 08^{\prime} 21.23^{\prime \prime} \mathrm{E}\end{array}$ & 3829 & 2.0 & $38-63$ & $1.41 \pm 0.05$ & $9.77 \pm 0.28$ & $3.03 \pm 0.11$ & $10 \pm 2$ & $3.05 \pm 0.20$ & $29.4 \pm 0.7$ & $9.6 \pm 0.7$ \\
\hline HF17-2 & $\begin{array}{l}35^{\circ} 52^{\prime} 11.01^{\prime N} \mathrm{~N} \\
94^{\circ} 08^{\prime} 21.23^{\prime \prime} \mathrm{E}\end{array}$ & 3829 & 5.0 & $38-63$ & $1.37 \pm 0.05$ & $7.34 \pm 0.24$ & $1.78 \pm 0.08$ & $10 \pm 5$ & $2.41 \pm 0.17$ & $32.8 \pm 1.5$ & $13.6 \pm 1.1$ \\
\hline HF17-3 & $\begin{array}{l}35^{\circ} 52^{\prime} 11.01^{\prime \prime N} \\
94^{\circ} 08^{\prime} 21.23^{\prime \prime} \mathrm{E}\end{array}$ & 3829 & 10.0 & $38-63$ & $1.36 \pm 0.05$ & $7.08 \pm 0.23$ & $1.90 \pm 0.08$ & $10 \pm 5$ & $2.33 \pm 0.17$ & $42.3 \pm 3.4$ & $17.7 \pm 1.9$ \\
\hline $\mathrm{HHC} 4-1$ & $\begin{array}{l}35^{\circ} 53^{\prime} 34.60 " \mathrm{~N} \\
93^{\circ} 29^{\prime} 34.99^{\prime \prime} \mathrm{E}\end{array}$ & 4300 & 0.80 & $38-63$ & $1.99 \pm 0.20$ & $5.97 \pm 0.22$ & $1.67 \pm 0.06$ & $15 \pm 5$ & $2.80 \pm 0.19$ & $43.5 \pm 2.01$ & $16.5 \pm 1.3$ \\
\hline HR2-1 & $\begin{array}{l}35^{\circ} 53^{\prime} 08.63^{\prime N} \mathrm{~N} \\
93^{\circ} 49^{\prime} 30.17^{\prime \prime E}\end{array}$ & 4052 & 0.70 & $38-63$ & $2.42 \pm 0.10$ & $9.45 \pm 0.27$ & $1.52 \pm 0.05$ & $15 \pm 5$ & $2.91 \pm 0.19$ & $60.7 \pm 2.74$ & $21.1 \pm 1.6$ \\
\hline $\mathrm{NMH1-1}$ & $\begin{array}{l}36^{\circ} 02^{\prime} 39.36^{\prime \prime N} \\
96^{\circ} 26^{\prime} 15.36^{\prime \prime} \mathrm{E}\end{array}$ & 3436 & 0.4 & $38-63$ & $1.68 \pm 0.06$ & $10.1 \pm 0.28$ & $2.05 \pm 0.10$ & $10 \pm 5$ & $3.09 \pm 0.21$ & $70.5 \pm 2.9$ & $22.8 \pm 1.8$ \\
\hline $\mathrm{NMH} 1-4$ & $\begin{array}{l}36^{\circ} 02^{\prime} 39.36^{\prime \prime} \mathrm{N} \\
96^{\circ} 26^{\prime} 15.36^{\prime \prime} \mathrm{E}\end{array}$ & 3436 & 6.0 & $38-63$ & $1.65 \pm 0.05$ & $11.6 \pm 0.32$ & $2.73 \pm 0.10$ & $10 \pm 5$ & $3.39 \pm 0.23$ & $85.7 \pm 4.8$ & $25.3 \pm 2.2$ \\
\hline ALK3-1 & $\begin{array}{l}35^{\circ} 32^{\prime} 23.98^{\prime \prime N} \\
97^{\circ} 11^{\prime} 49.70^{\prime \prime E}\end{array}$ & 4179 & 1.2 & $38-63$ & $1.02 \pm 0.04$ & $5.30 \pm 0.18$ & $1.40 \pm 0.07$ & $10 \pm 3$ & $2.01 \pm 0.13$ & $32.0 \pm 1.2$ & $15.9 \pm 1.2$ \\
\hline ALK4-1 & $\begin{array}{l}35^{\circ} 35^{\prime} 03.68^{\prime \prime N} \\
97^{\circ} 12^{\prime} 19.11^{\prime \prime E}\end{array}$ & 4108 & 0.4 & $38-63$ & $1.19 \pm 0.05$ & $7.91 \pm 0.25$ & $1.95 \pm 0.08$ & $15 \pm 5$ & $2.41 \pm 0.16$ & $46.3 \pm 2.5$ & $19.2 \pm 1.7$ \\
\hline ALK4-2 & $\begin{array}{l}35^{\circ} 35^{\prime} 03.68^{\prime \prime N} \\
97^{\circ} 12^{\prime} 19.11^{\prime \prime} \mathrm{E}\end{array}$ & 4108 & 1.1 & $38-63$ & $1.50 \pm 0.05$ & $10.9 \pm 0.31$ & $2.68 \pm 0.10$ & $20 \pm 5$ & $2.82 \pm 0.18$ & $50.4 \pm 2.3$ & $17.9 \pm 1.4$ \\
\hline ALK4-3 & $\begin{array}{l}35^{\circ} 35^{\prime} 03.68^{\prime \prime N} \\
97^{\circ} 12^{\prime} 19.11^{\prime \prime} \mathrm{E}\end{array}$ & 4108 & 2.4 & $38-63$ & $1.09 \pm 0.05$ & $5.14 \pm 0.18$ & $1.34 \pm 0.07$ & $20 \pm 5$ & $1.76 \pm 0.12$ & $50.2 \pm 2.6$ & $28.6 \pm 2.4$ \\
\hline CK2-1 & $\begin{array}{l}36^{\circ} 51^{\prime} 42.63^{\prime \prime} \mathrm{N} \\
98^{\circ} 56^{\prime} 03.42^{\prime \prime} \mathrm{E}\end{array}$ & 3180 & 9.0 & $38-63$ & $1.80 \pm 0.04$ & $9.61 \pm 0.60$ & $2.3 \pm 0.4$ & $10 \pm 3$ & $3.00 \pm 0.24$ & $297.9 \pm 31.57$ & $99.2 \pm 13.1$ \\
\hline GH1-1 & $\begin{array}{l}36^{\circ} 14^{\prime} 44.95^{\prime \prime N} \\
99^{\circ} 49^{\prime} 24.42^{\prime \prime} \mathrm{E}\end{array}$ & 3036 & 3.0 & $90-125$ & $3.19 \pm 0.04$ & $15.6 \pm 0.80$ & $2.6 \pm 0.4$ & $10 \pm 3$ & $4.55 \pm 0.32$ & $259.9 \pm 10.2$ & $57.1 \pm 4.5$ \\
\hline GH1-2 & $\begin{array}{l}36^{\circ} 14^{\prime} 44.95^{\prime N} \\
99^{\circ} 49^{\prime} 24.42^{\prime \prime} \mathrm{E}\end{array}$ & 3036 & 6.0 & $38-63$ & $3.16 \pm 0.04$ & $17.3 \pm 0.90$ & $2.7 \pm 0.4$ & $10 \pm 3$ & $4.94 \pm 0.32$ & $409.1 \pm 34.0$ & $83.9 \pm 9.3$ \\
\hline GH2-1 & $\begin{array}{l}36^{\circ} 13^{\prime} 30.18^{\prime \prime N} \\
99^{\circ} 53^{\prime} 15.85^{\prime \prime} \mathrm{E}\end{array}$ & 2984 & 1.7 & $90-125$ & $2.33 \pm 0.04$ & $9.8 \pm 0.60$ & $2.1 \pm 0.3$ & $10 \pm 3$ & $3.26 \pm 0.23$ & $195.0 \pm 13.0$ & $59.9 \pm 5.8$ \\
\hline GH3-2 & $\begin{array}{l}36^{\circ} 12^{\prime} 38.94^{\prime N} \\
99^{\circ} 52^{\prime} 41.75^{\prime \prime} \mathrm{E}\end{array}$ & 2991 & 9.1 & $90-125$ & $2.26 \pm 0.04$ & $13.2 \pm 0.80$ & $2.3 \pm 0.3$ & $10 \pm 3$ & $3.39 \pm 0.24$ & $89.8 \pm 5.14$ & $26.5 \pm 2.4$ \\
\hline RYS3-2 & $\begin{array}{l}36^{\circ} 45^{\prime} 15.32^{\prime \prime N} \\
101^{\circ} 00^{\prime} 59.55^{\prime \prime}\end{array}$ & 3112 & 3.1 & $38-63$ & $1.85 \pm 0.04$ & $8.98 \pm 0.60$ & $1.9 \pm 0.3$ & $10 \pm 3$ & $3.01 \pm 0.22$ & $105.2 \pm 3.4$ & $35.0 \pm 2.8$ \\
\hline RYS4-1 & $\begin{array}{l}36^{\circ} 45^{\prime} 04.80^{\prime \prime N} \\
101^{\circ} 03^{\prime} 51.96^{\prime \prime}\end{array}$ & 3117 & 2.1 & $38-63$ & $1.85 \pm 0.04$ & $10.6 \pm 0.70$ & $2.0 \pm 0.3$ & $10 \pm 3$ & $3.21 \pm 0.23$ & $26.2 \pm 0.5$ & $8.1 \pm 0.6$ \\
\hline XS1-1 & $\begin{array}{c}36^{\circ} 40^{\prime} 47.20^{\prime \prime N} \\
101^{\circ} 03^{\prime} 48.87 " \mathrm{E}\end{array}$ & 3068 & 5.0 & $38-63$ & $2.26 \pm 0.04$ & $25.6 \pm 1.20$ & $2.2 \pm 0.3$ & $15 \pm 3$ & $4.35 \pm 0.32$ & $126.8 \pm 9.8$ & $29.2 \pm 3.1$ \\
\hline HL1-2 & $\begin{array}{l}36^{\circ} 13^{\prime} 17.13^{\prime \prime} \mathrm{N} \\
101^{\circ} 58^{\prime} 54.65^{\prime \prime} \mathrm{E}\end{array}$ & 2715 & 16.0 & $38-63$ & $2.01 \pm 0.04$ & $11.3 \pm 0.70$ & $2.2 \pm 0.3$ & $10 \pm 3$ & $3.26 \pm 0.25$ & $90.3 \pm 2.81$ & $27.7 \pm 2.3$ \\
\hline TD1-1 & $\begin{array}{l}35^{\circ} 05^{\prime} 41.52^{\prime \prime N} \\
100^{\circ} 45^{\prime} 39.54^{\prime \prime}\end{array}$ & 3447 & 5.6 & $90-125$ & $1.92 \pm 0.04$ & $11.74 \pm 0.70$ & $2.1 \pm 0.3$ & $10 \pm 3$ & $3.10 \pm 0.22$ & $99.7 \pm 5.9$ & $32.2 \pm 3.0$ \\
\hline TD2-3 & $\begin{array}{l}34^{\circ} 52^{\prime} 15.88^{\prime \prime N} \\
100^{\circ} 50^{\prime} 04.48^{\prime \prime}\end{array}$ & 3627 & 15.0 & $90-125$ & $1.62 \pm 0.04$ & $14.98 \pm 0.80$ & $2.8 \pm 0.4$ & $10 \pm 3$ & $3.02 \pm 0.22$ & $170.1 \pm 12.6$ & $56.3 \pm 5.9$ \\
\hline GN1-1 & $\begin{array}{c}36^{\circ} 56^{\prime} 25.82^{\prime N} \\
100^{\circ} 39^{\prime} 29.46^{\prime \prime}\end{array}$ & 3248 & 16.0 & $38-63$ & $1.75 \pm 0.04$ & $13.5 \pm 0.80$ & $3.0 \pm 0.4$ & $10 \pm 3$ & $4.49 \pm 0.33$ & $139.1 \pm 4.1$ & $31.0 \pm 2.4$ \\
\hline
\end{tabular}


a.s.l. But it is approximately $\sim 3,000 \mathrm{~m}$ a.s.l. in the Chaka-Gonghe Basin, the Qinghai Lake basin, and even much lower in the further southeast. Many types of glacial landforms and deposits have been developed in the U-shaped valleys, which are etched in the slopes on both sides of the mountains around the basins. The paleo-moraines are preserved at the elevations of $5,000-4,500 \mathrm{~m}$ a.s.l. in the western mountains of this region. But these forms are located at lower elevations (3,900-3,600 $\mathrm{m}$ a.s.l.) in the east of the mountains (Owen et al., 2006; Wang et al., 2013). The regional climate types are divided into three subzones: the arid feature and lower mean annual temperature in the Kunlun Mountains and the Chaka-Gonghe region, the semi-arid and moderate temperature in the Qilian and Qinghai Lake area, and the relatively humid and warm climate condition in southeastern Qinghai Province. The mean annual precipitation of the regions mentioned above not only depends on the atmospheric moisture but is also related to the topographic relief in the mountains (Yu et al., 2013).

At the present day, annual precipitation in the western region of the NETP is $100-200 \mathrm{~mm}$, with the majority of it occurring during the summer season. The mean annual temperature is $2.0^{\circ} \mathrm{C}$; the mean January temperature at the Wudaoliang meteorological station $(4,780 \mathrm{~m}$ a.s.l.), which is $50 \mathrm{~km}$ to the south, is $-8.4^{\circ} \mathrm{C}$, and the mean July temperature is $12.1^{\circ} \mathrm{C}$ (Zhang et al., 2013). Owing to the low annual mean temperature, permafrost features are widespread in the study area. Vegetation in the drainage basins consists of dry alpine steppe communities (Stauch et al., 2017). In the eastern regions, the annual mean temperature is $-0.3^{\circ} \mathrm{C}$, the highest monthly mean temperature is $10.9^{\circ} \mathrm{C}$ (July), and the lowest monthly mean temperature is $-13.5^{\circ} \mathrm{C}$ (January). The annual mean precipitation is $300-400 \mathrm{~mm}$. The annual mean evaporation is about $1,300 \mathrm{~mm}$ (Liu et al., 2011). Alpine steppe and alpine meadow are the main vegetation types in the eastern region.

\section{Sample Collection}

The coordinates and elevations of all sampling sections in this study are shown in Table $\mathbf{1}$, and all profile photos are shown in Figure 2, in which the sampling sediment layers and dating results are displayed. The sections HF4, HF8, HF17, HHC, and $\mathrm{HR}$ are located in the Golmud River drainage basin. The first three sections consist of decimeters-thick alluvial sands to coarse gravels with moderate sorting, sub-rounding, and horizontal bedding traits. The alluvial fans are highly dissected, and several bluffs are developed due to river erosion. The section heights are 3,24 , and $13 \mathrm{~m}$, respectively. The latter two are characterized by weakly sorted fine gravels, with a grain diameter of $2-5 \mathrm{dm}$, and sand lenticles sandwiched between the gravel layers. The sections NMH1, ALK3, and ALK4 lie on the Nuomuhong River and the Alake Lake catchments in the eastern Kunlun Mountains. The section NMH1 is a $\sim 8$-m-high alluvial stack and comprises sub-rounded and poorly sorted alluvial sand and gravel layers, and the upper and middle layers contain sparse boulders. The section ALK3 is $7 \mathrm{~m}$ thick and composed of weakly rounded and sorted gravels, which show horizontal layers, sandwiching irregular sand layers. The alluvial deposits are capped by a discontinuous, decimeter-to-meter-thick layer of loess sediment. The section ALK4 comprises a 2.5-m-thick alluvial toe deposit comprising rufous, tawny horizontally bedded clay, and silt layers in the upper half and sand to five gravel layers in the lower part. The sections CK2, GH1, and $\mathrm{GH} 2$ are on the piedmont alluvial fan cascades from Ela Mountain and the Qinghainan Mountains. The section CK2 is a $10-\mathrm{m}$-thick alluvial stock and sandwiches half-meter sand lenticles. Inversely, the sections $\mathrm{GH} 1$ and $\mathrm{GH} 2$ are predominantly alluvial gravel deposits with 10-dm-thick sand lenticles, and have a thickness of 6.0 and $2.5 \mathrm{~m}$. The sections RYS3, RYS4, and XS1 are situated in the piedmonts of Riyue Mountain. Sections RYS3 and RYS4 mainly comprise crudely stratified meter and decimeter beds of fanglomerates and debris flows (section RYS4 contains abundant boulders), with a section thickness of 3.5 and $3.0 \mathrm{~m}$. Section XS1 is a set of alluvial deposits that contains some boulders, with a thickness of $15 \mathrm{~m}$. In the easternmost segment of the NETP, there are four sections, HL1, TD1, TD2, and GN1, which merge with the distinctive alluvial deposits, with stratification, interbedding, and clear sand and gravels, also containing a few sand lenticles. The four sections have a section thickness of $25,20,15$, and $18 \mathrm{~m}$, respectively. A total of 26 samples were collected for OSL dating with the stratigraphic order from the alluvial sections mentioned above.

\section{Optically Stimulated Luminescence Dating}

The OSL samples were collected by driving iron tubes $(25 \mathrm{~cm}$ in length and $5 \mathrm{~cm}$ in diameter) into newly cleaned vertical sections. Each tube was covered with black plastic bags and was sealed with black packaging tape to avoid light exposure and moisture losses. In the laboratory, $3-\mathrm{cm}$ sections of the sediments at each end of the cylinders were scraped away and were used for water content and dose rate measurements. The unexposed part in the middle of the tube was used for equivalent dose $\left(D_{e}\right)$ determination. We followed the procedures of Lai (2010) to chemically pretreat OSL samples to remove feldspar contamination that might lead to age underestimation (Lai and Brückner, 2008). We checked the purity of the retrieved quartz by infrared light stimulation $(830 \mathrm{~nm})$, and no obvious IRSL was observed. The pure quartz samples were mounted on the center $(0.7 \mathrm{~cm}$ in diameter $)$ of stainless steel discs with a diameter of $0.97 \mathrm{~cm}$ with silicone oil.

We used an automated Risø TL/OSL-DA-20 reader for OSL dating, which was equipped with a ${ }^{90} \mathrm{Sr} /{ }^{90} \mathrm{Y}$ beta source for OSL measurements at the Qinghai Institute of Salt Lakes, Chinese Academy of Sciences. The procedure involved stimulation by blue LEDs at $130^{\circ} \mathrm{C}$ for $40 \mathrm{~s}$ and signal detection using 7.5-mm-thick U-340 filters. We used neutron activation analysis to determine the $\mathrm{U}, \mathrm{Th}$, and $\mathrm{K}$ concentration at the China Institute of Atomic Energy in Beijing. For grains in the range of $38-63 \mu \mathrm{m}$, the $a$ efficiency was taken as $0.035 \pm 0.003$ (Lai et al., 2008). The cosmic ray dose rate was estimated for each sample as a function of depth, altitude, and geomagnetic latitude (Prescott and Hutton, 


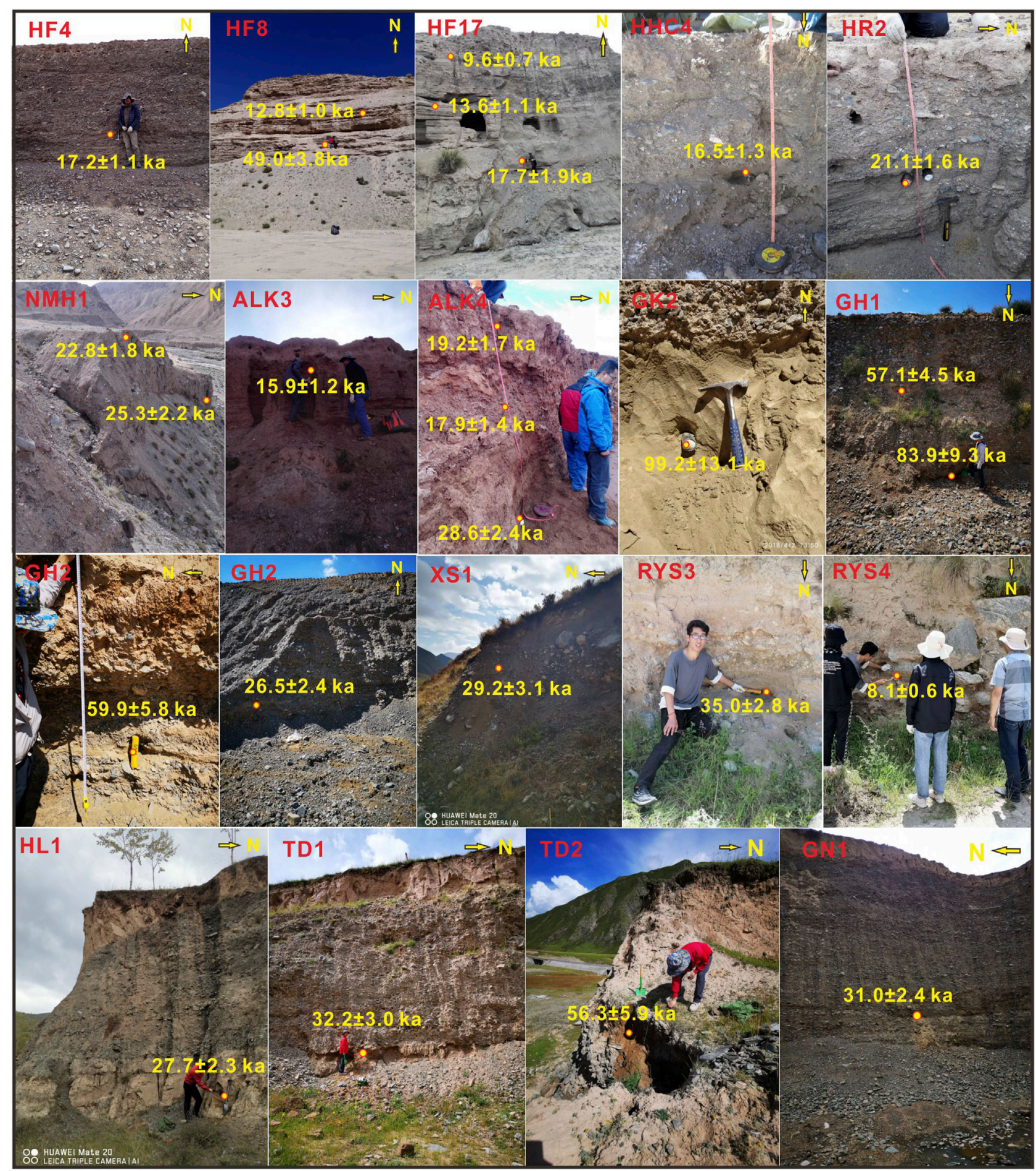

FIGURE 2 | Photos showing profile sedimentary features of all alluvial sections involved in the current study and sampling layers and their corresponding dating results.

1994). Water content was calculated from moisture mass/dry mass (Aitken, 1985), and most of the measured results were near $0 \%$, which is attributed to the arid modern environment. However, considering the uncertainties associated with burial and sediment types, values of $10-15 \%$ were estimated for the water content and dose rate calculations (Table 1).

The equivalent dose $\left(D_{e}\right)$ was determined using a combination of the single-aliquot regenerative dose (SAR) 
protocol Murray and Wintle (2000) and a standardized growth curve (SGC) method (Lai and Wintle, 2006), that is, the SARSGC method was applied. For each sample, six aliquots were measured using the SAR to construct the SGC, and then twelve aliquots were measured using the SGC. The final $D_{e}$ for a sample was given by the average of all eighteen $D_{e}$ values. Figure 3 shows the typical OSL decay curves and growth curves for ALK4-1 and GH1-1, respectively, suggesting that the OSL signals were from the fast component. Preheat plateau tests were conducted on samples ALK4-3 and RYS3-2, and a preheat plateau was clearly identified from 240 to $280^{\circ} \mathrm{C}$ in both samples (Figure 4). Based on the results, a preheat of $260^{\circ} \mathrm{C}$ for $10 \mathrm{~s}$ and a second heat of $220^{\circ} \mathrm{C}$ for $10 \mathrm{~s}$ were used for $D_{e}$ measurements. Signals of the first $0.64 \mathrm{~s}$ of stimulation were integrated for growth curve construction after back ground subtraction.

Dose recovery tests (Murray and Wintle, 2003), which can validate the SAR procedure, were performed on samples ALK43 and RYS3-2, and six aliquots of each sample were tested. The ratios of the average measured dose (54.4 and $106.6 \mathrm{~Gy}$ ) to the given dose ( 50 and $105 \mathrm{~Gy}$ ), which fall into the acceptable range of $0.9-1.1$, suggested that the SAR protocol was suitable for $D_{e}$ determination in this study (Figure 4). Recuperation was calculated by comparing the sensitivity-corrected OSL signal of $0 \mathrm{~Gy}$ to the sensitivity-corrected natural signal to check the thermo-transferred signals. In this study, recuperations for different preheat temperatures were less than $5 \%$ of the natural signal, which was negligible (Figure 4). The "recycling ratio" was introduced to check for sensitivity change correction Murray and Wintle (2000), and for most aliquots, the recycling ratios fell into the acceptable range of 0.9-1.1 (Figure 4).

\section{RESULTS}

Considerable success has been obtained from applying OSL dating to dammed fluvial-lacustrine sediments in the central southern TP, with well-bleached samples that yielded accurate age estimates (Liu et al., 2015; Chen et al., 2016; Liu et al., 2018; Wang et al., 2019). Consistent ages of eolian sand lenticels and adjacent alluvial sedimentary layers in the alluvial delta fan supported the reliability of OSL dating of alluvial sediments in the eastern Kunlun Mountains (An et al., 2018a). A modern fluvial sediment sample from the Kunlun River catchment (proximity to the HL3), which produced a $D_{e}$ of $1.20 \pm$ $0.20 \mathrm{~Gy}(0.4 \pm 0.1 \mathrm{ka})$ at a depth of $0.3 \mathrm{~m}$, indicated a negligible residual dose in samples from the drainage basin (An et al., 2021).

The OSL ages determined in the current study are presented in Table 1, and the quoted chronology data from previous studies are listed in Supplementary Table S1. The entire data on alluvial fans cover from the most western part of the eastern Kunlun Mountains to the most eastern end of Qinghai Lake and Riyue Mountain, occupying the main monsoon-dominated region on the NETP. The initiating of the alluvial fans involved in this investigation occurred since the age of $99.2 \pm 13.1 \mathrm{ka}$. Inferences
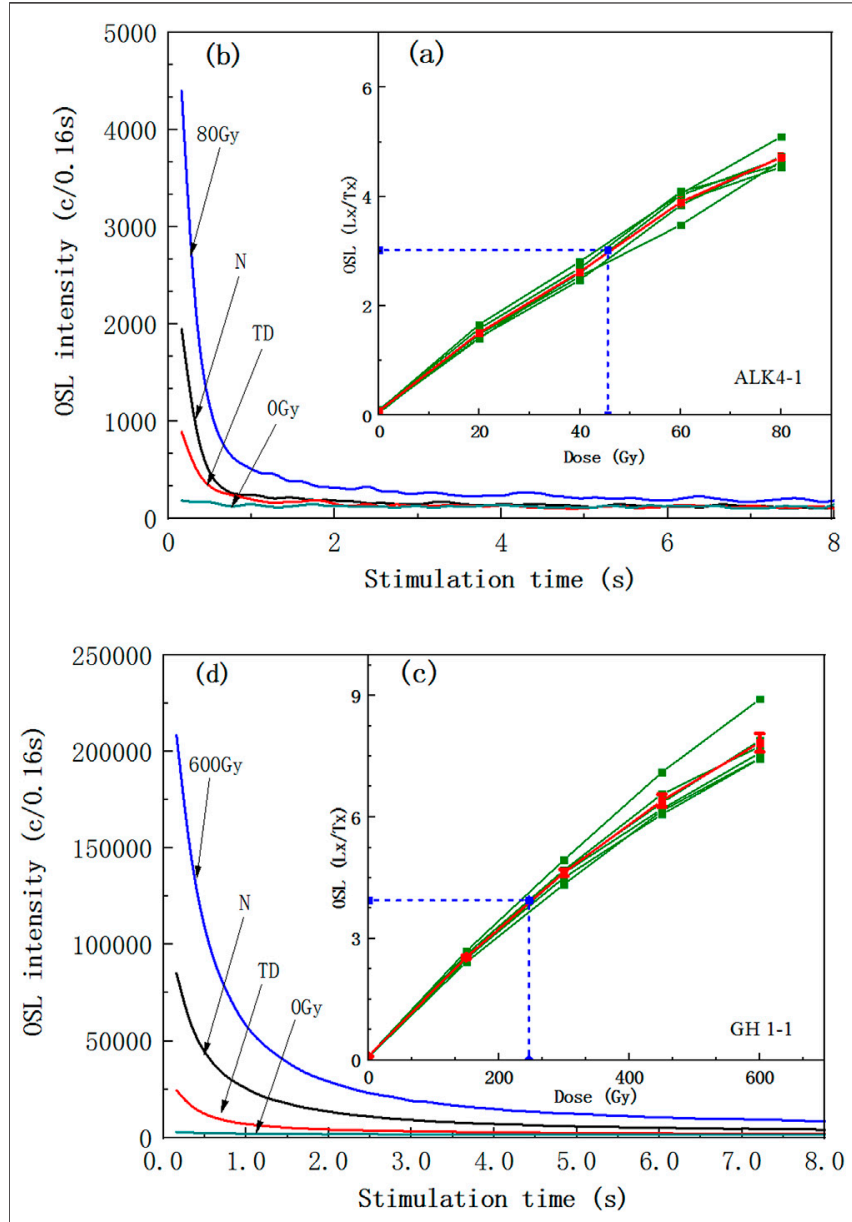

FIGURE 3 | Luminescence characteristics of samples ALK4-1 and GH1$1 ; \mathbf{A})$ and (C) display the growth curves of six aliquots and the standard growth curve (SGC) (red lines), which is taken as the average of the six growth curves; (B) and (D) display the decay curves for the natural (N) and regenerative doses of $\mathrm{R} 3,0 \mathrm{~Gy}$, and test dose (TD), respectively. The points (solid squares) defining each individual growth curve are depicted with error bars. The horizontal and vertical blue dashed lines indicate the projection of the average of the sensitivity-corrected natural signals of the six aliquots onto the SGC.

suggested that there are older alluvial sediments than these. However, the older geomorphic processes could have greater odds of tectonic influence, especially the surface uplift; thus, we mainly focused on the alluvial formation since the Last Interglaciation. The youngest ages for a debris flow that is covered by loess have a date of $8.1 \pm 0.6 \mathrm{ka}$. Analysis of the entire forming ages of the alluvial fans on the NETP suggests that the Last Glaciation and Deglaciation were the main developing stages, and the alluvial fans of different scales filled diffusely in the drainage basins of this region. The MIS 3 period is another relative activity stage of alluvial geomorphic processes. From 83.9.1 \pm 9.36 to $99.2 \pm 13.1 \mathrm{ka}$, the strong hydrological processes promoted the development of the alluvial fans. This stage corresponded to the late period of the MIS 5. Analyses of these dating results from regionalism showed that the alluvial 


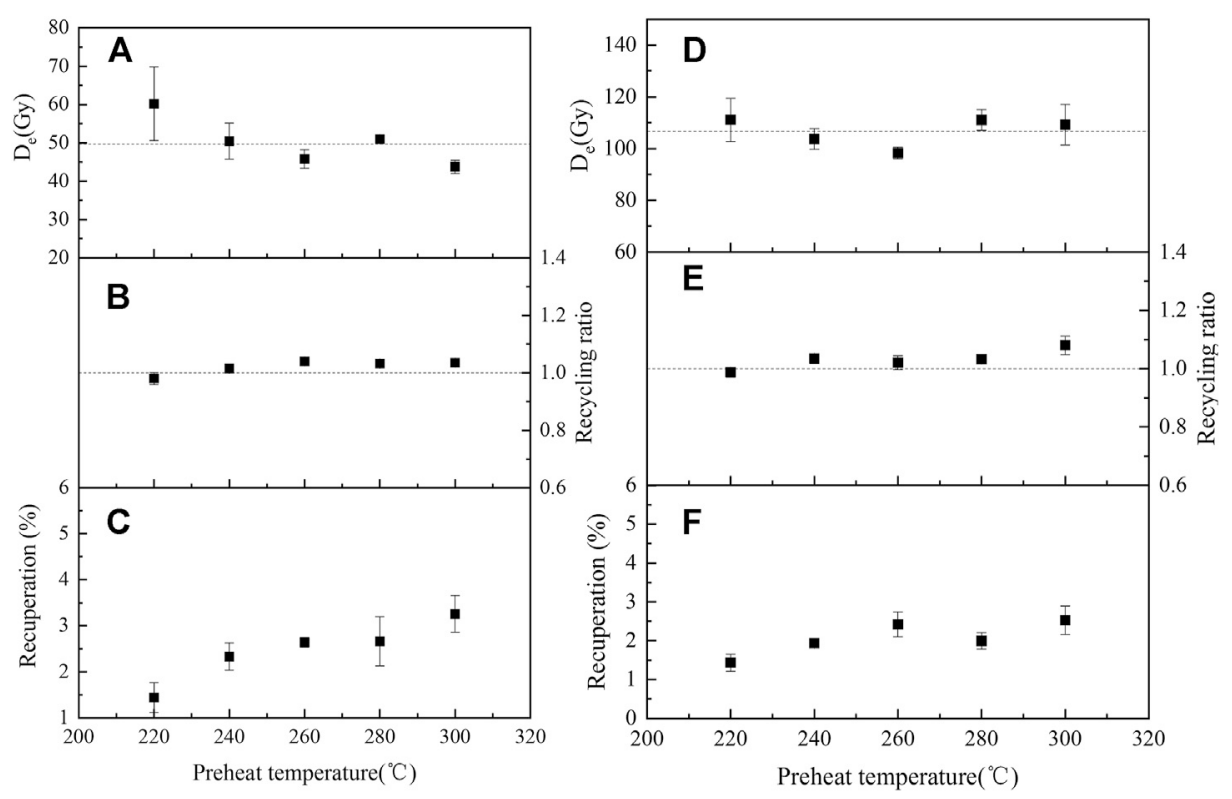

FIGURE 4 | Results of preheat plateau tests (A) and (D), recuperation (C) and (F), and recycling ratio (B) and (E) for ALK4-3 (left) and RYS3-2 (right). The equivalent dose $\left(D_{e}\right)$ of each data point is the mean of four aliquots. The final chosen preheat temperature for quartz OSL dating in this study was $260^{\circ} \mathrm{C}$.

fans in the drainage basins of the western high mountains yielded the broad-spectrum ages ranging from the Last Interglaciation to early Holocene periods. Inversely, in the eastern lower mountains, the age data were mainly concentrated in the MIS 3 period, and other climate stage ages were relatively scarce. These results could be ascribed to the high mountain topography (altitude variation from $\sim 4,000$ to 6,000 a.s.l), which was more sensitive to the moisture fluctuation dominated by the hemispherical atmospheric circulations.

\section{DISCUSSION}

\section{The Climatic/Tectonic Influences on the Alluvial Fans Since $200 \mathrm{Ka}$}

The valley fills or the piedmont cascade of alluvial detritus in the arid and semi-arid drainage basins are commonly ascribed to climate change or tectonic uplift (Chen et al., 2011; Zhang et al., 2014; An et al., 2018a; Tao et al., 2020). In recent decades, various geomorphic units in the northeastern margin of the NETP, such as alluvial fans, fluvial terraces, high-stand lacustrine sediments, sand dunes, and moraines, have been intensively studied. Almost all previous studies have focused on the effect of climate changes for the surface geomorphic dynamics since the penultimate Interglaciation, although the influence of tectonic uplift could not be ruled out in some local places (for the specific statistics of the references, see Table 2). As shown in Table 2, the paleoclimate change is one of the major factors controlling depositional processes, and it played a prominent role in the formation of various geomorphic units on the NETP. Most landform processes in the Golmud River of the eastern Kunlun Mountains, including impressive piedmont alluvial fans and delta alluvial fans, stretch into the arid basin and are related to climate change rather than surface uplift (Owen et al., 2006; An et al., 2018a, b). The formation of the alluvial fan deposits is related to the hydrological variation in the mountains at the southern border of the Heihai Lake, which is located in the headwater area of the Golmud River, and it influenced the variation of the lake level through blockage of the lake outflow (Stauch et al., 2017). The synthetic wetness index from various geomorphic units in the mountain valleys of the eastern Kunlun Mountains showed a good correspondence to moisture records that were controlled by the ISM, showing their paleoclimatic cause (An et al., 2018a). In a study of the ${ }^{10} \mathrm{Be}$ flux of lacustrine sediments collected at Kunlun Pass, Chen et al. (2021) suggested that there was a shift in the dominant influence in the region from monsoons to westerlies after $4 \mathrm{ka} \mathrm{BP}$. In the Qinghai Lake watershed, alluvial sediments mainly deposited during the middle-to-late MIS 3, and they had a paleoclimatic origin (Liu et al., 2017). A stream-dominated fan in the Xining Basin, which lies on the margin of the NETP, was reported by Gao et al. (2018), Their results indicated that a climate-dominated transition of the sedimentary environment from high- to low-energy fans occurred from the penultimate glacial to the last interglacial. A database of the terrace ages of Quaternary fluvial terraces on the $\mathrm{TP}$ and surrounding orogenic belts was integrated by Tao et al. (2020), and they grouped terraces into the three regional climate systems, the ISM, EASM, and westerlies, and found that the formation of terraces younger than $200 \mathrm{ka}$ was mainly controlled by climate changes. However, the incision of fluvial terraces in the Golmud River drainage basin was ascribed to the transitory surface uplift by Chen et al. (2011). They argued that the valley fills occurred during the tectonic stable stage of the Last Glaciation. From the analysis mentioned above, we can draw a 
TABLE 2 | Statistics of climatic/tectonic forcing factors for various geomorphic units from previous studies in the Northeastern Tibetan Plateau since 200 ka.

\begin{tabular}{|c|c|c|c|c|c|}
\hline Covered areas & Geomorphic units & $\begin{array}{l}\text { Dating } \\
\text { methods }\end{array}$ & Paleoclimatic stage & $\begin{array}{l}\text { Forcing } \\
\text { factors }\end{array}$ & Authors \\
\hline $\begin{array}{l}\text { Southern margin of the Qaidam } \\
\text { Basin, eastern Kunlun Mountains }\end{array}$ & $\begin{array}{l}\text { Moraines } \\
\text { Alluvial fans } \\
\text { Pediments and terraces }\end{array}$ & SED, OSL & $\begin{array}{l}\text { Penultimate Glaciation, Last Glaciation, Last } \\
\text { Deglaciation, and middle Holocene }\end{array}$ & Climate & $\begin{array}{l}\text { Owen et al. } \\
(2006)\end{array}$ \\
\hline $\begin{array}{l}\text { Golmud River catchment on the } \\
\text { Northeastern Tibetan Plateau }\end{array}$ & $\begin{array}{l}\text { Drainage and lacustrine } \\
\text { sediments }\end{array}$ & $\begin{array}{l}\text { ESR } \\
\text { U-series }\end{array}$ & $\begin{array}{l}\text { Penultimate Interglaciation } \\
\text { Last Interglaciation }\end{array}$ & Climate & $\begin{array}{l}\text { Cui et al. } \\
(1999)\end{array}$ \\
\hline $\begin{array}{l}\text { Northern margin of the Tibetan } \\
\text { Plateau }\end{array}$ & $\begin{array}{l}\text { Valley fills } \\
\text { Fluvial terraces }\end{array}$ & OSL & $\begin{array}{l}\text { Last Glaciation } \\
\text { Early-to-middle Holocene }\end{array}$ & Climate & $\begin{array}{l}\text { Wang et al. } \\
(2009)\end{array}$ \\
\hline $\begin{array}{l}\text { Heihai Lake catchment of the eastern } \\
\text { Kunlun Mountains }\end{array}$ & $\begin{array}{l}\text { Alluvial fans } \\
\text { Eolian sediments } \\
\text { Fluvial terraces } \\
\text { Drainage and lacustrine } \\
\text { sediments }\end{array}$ & OSL & Last Deglaciation and Holocene & Climate & $\begin{array}{l}\text { Stauch et al. } \\
\text { (2017) }\end{array}$ \\
\hline $\begin{array}{l}\text { Nalinggele River catchment of the } \\
\text { eastern Kunlun Mountains }\end{array}$ & Valley fills and fluvial terraces & OSL & $\begin{array}{l}\text { Last Glaciation } \\
\text { Early-to-middle Holocene }\end{array}$ & Climate & $\begin{array}{l}\text { Chang et al. } \\
(2017)\end{array}$ \\
\hline Northeastern Tibetan Plateau & $\begin{array}{l}\text { Alluvium, eolian sediments, } \\
\text { and sand wedges }\end{array}$ & OSL & $\begin{array}{l}\text { Last Glaciation } \\
\text { Last Deglaciation }\end{array}$ & Climate & $\begin{array}{l}\text { Liu et al. } \\
(2017)\end{array}$ \\
\hline $\begin{array}{l}\text { Huanghui River on the Northeastern } \\
\text { Tibetan Plateau }\end{array}$ & Alluvial fans & OSL & $\begin{array}{l}\text { Penultimate Glaciation } \\
\text { Last Interglaciation }\end{array}$ & Climate & $\begin{array}{l}\text { Gao et al. } \\
(2018)\end{array}$ \\
\hline $\begin{array}{l}\text { Heihai Lake catchment of the eastern } \\
\text { Kunlun Mountains }\end{array}$ & $\begin{array}{l}\text { Fluvial terraces } \\
\text { High-stand lacustrine } \\
\text { sediments } \\
\text { Lake shoreline }\end{array}$ & OSL, ${ }^{14} \mathrm{C}$ & Late Holocene & Climate & $\begin{array}{l}\text { An et al. } \\
\text { (2018a) }\end{array}$ \\
\hline $\begin{array}{l}\text { Southern margin of the Qaidam } \\
\text { Basin, eastern Kunlun Mountains }\end{array}$ & $\begin{array}{l}\text { Alluvial fans } \\
\text { Eolian sediments } \\
\text { Fluvial terraces } \\
\text { Swamp sediments }\end{array}$ & OSL & Last Deglaciation and Holocene & Climate & $\begin{array}{l}\text { An et al. } \\
\text { (2018b) }\end{array}$ \\
\hline Across the Tibetan Plateau & Fluvial terraces & $\begin{array}{l}\text { Integrated age } \\
\text { data }\end{array}$ & Since the Penultimate Interglaciation & Climate & $\begin{array}{l}\text { Tao et al. } \\
(2020)\end{array}$ \\
\hline $\begin{array}{l}\text { Golmud River catchment on the } \\
\text { Northeastern Tibetan Plateau }\end{array}$ & $\begin{array}{l}\text { Alluvial fans, dammed lake } \\
\text { sediments, and loess }\end{array}$ & OSL & $\begin{array}{l}\text { Last Glaciation } \\
\text { Last Deglaciation } \\
\text { Early Holocene }\end{array}$ & Climate & $\begin{array}{l}\text { An et al. } \\
(2021)\end{array}$ \\
\hline $\begin{array}{l}\text { Golmud River catchment on the } \\
\text { Northeastern Tibetan Plateau }\end{array}$ & $\begin{array}{l}\text { Valley fills } \\
\text { Slope deposits } \\
\text { Fluvial terraces }\end{array}$ & OSL, ${ }^{14} \mathrm{C}$ & $\begin{array}{l}\text { Last Glaciation } \\
\text { Last Deglaciation } \\
\text { Early-to-middle Holocene }\end{array}$ & $\begin{array}{l}\text { Climate and } \\
\text { tectonics }\end{array}$ & $\begin{array}{l}\text { Chen et al. } \\
\text { (2011) }\end{array}$ \\
\hline
\end{tabular}

conclusion that the alluvial fans developed in the studied area responded to the paleoclimatic fluctuations rather than the tectonic uplifts during the late Quaternary.

\section{The Glacial Forcing Mechanism on Alluvial Fans' Development}

Enhanced evidence suggested that the dynamic of alluvial fans on the NETP showed a periglacial origin, especially the high relief and elevation regions (Van Der Woerd et al., 2002; Owen et al., 2006; Stauch et al., 2017; An et al., 2018a; Cui et al., 2020). The glacier activities in the high mountains produced abundant glacial debris in the piedmont during glaciation periods (Owen et al., 2006). Subsequently, the glacial debris cascaded onto alluvial fans and was transported into tributary and main valleys by abundant glacier meltwater and finally completed valley filling (An et al., 2018b). The process of aggradations from the piedmont to the alluvial delta fan was probably multistage or leapt forward to the downstream drainage basin, as there are several reservoir segments in the main valley through which detrital materials are transported step by step (Wang et al., 2009; An et al., 2018b).
Therefore, the multistage alluvial fans or valley fills in drainage basins and the margin area of arid basins are the main linkage between the orographic glaciers and the distal lower basins. The dating age for the moraine sediments is limited because there are few suitable chronology methods or dating materials (Cui et al., 2020). Thus, the dynamics of the alluvial fans reflect environmental/climatic information of the provenance area, namely, glacial activity processes. Both the geomorphic dynamics showed more consistent feedback to each other on the orbital timescale. In view of the foregoing, we compared the developing ages of alluvial fans in different areas on the NETP with those of the glacial advances from the eastern Kunlun Mountains, the Dalijia Peak of eastern Riyue Mountain, the Queer Shan ranges of the eastern TP, and Yulong Mountain of the southeastern TP (Owen et al., 2006; Wang et al., 2013; Ou et al., 2014; He et al., 2016) (Figures 5A,B). There is broad consistency in the timing of both geomorphic dynamics, especially in the early Holocene, Last Deglaciation, and MIS 2. The stages MIS 3 and late MIS 5 were also relatively active periods for the alluvial fans and glaciers. Even in the records of both geomorphic processes, the Younger Dryas (YD) event can be 


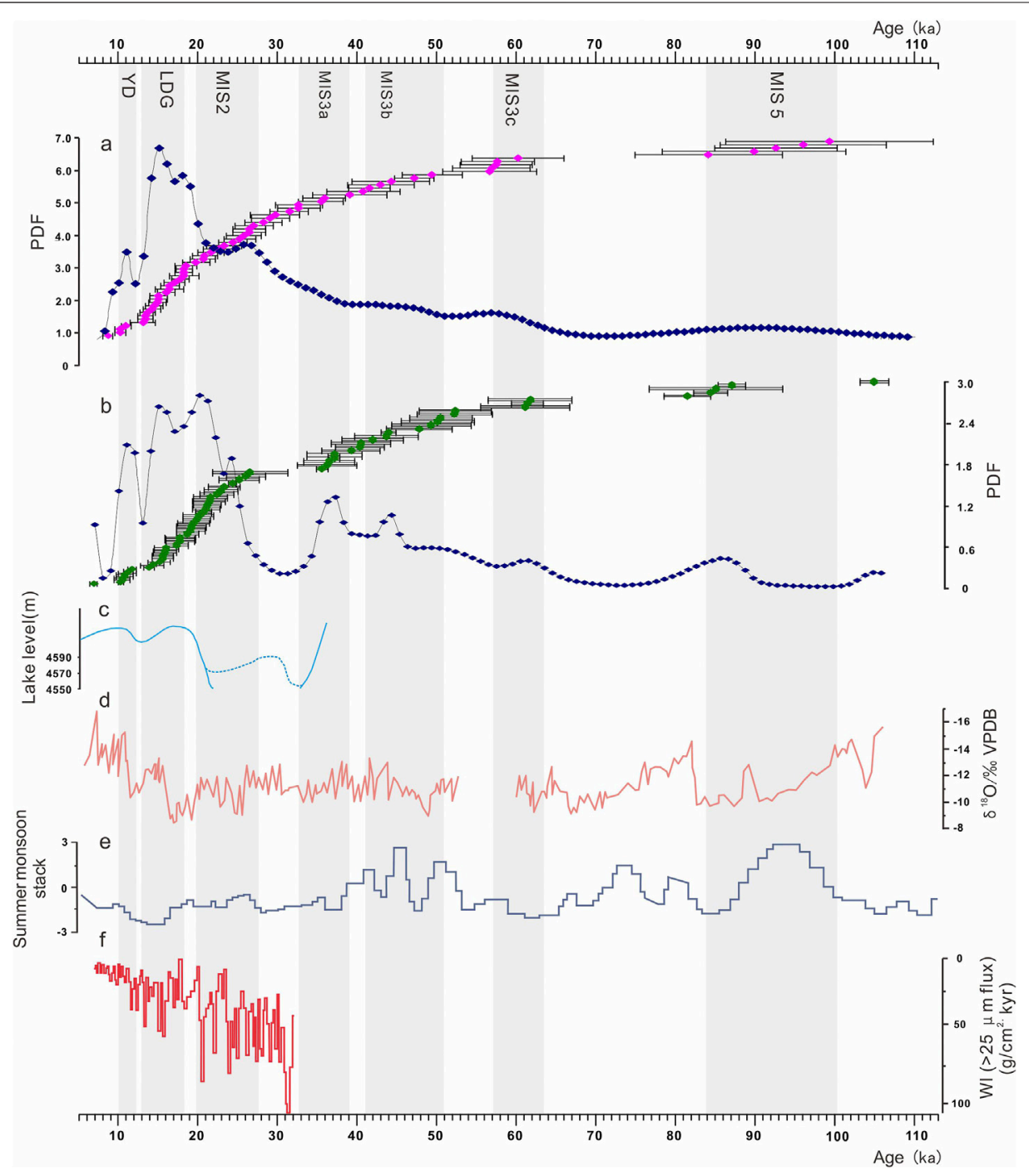

FIGURE 5 | Comparison of alluvial fan and glacial advance OSL ages from the present study with proxy climate indicators. (A) Purple rhombuses represent alluvial fan ages with error bars. (B) Green rhombuses represent glacial advance ages with error bars. The string of blue rhombus lines in (A) and (B) are the probability density function (PDF) curves from the ages. (C) Reconstructed lake level for the Taro Co lake system, southwestern TP. Dashed line represents the probable maximum lake level (modified by Alivernini et al., 2018). (D) $\delta^{18} \mathrm{O}$ record of the stalagmites from the Xiaobailong cave, southwestern TP (Cai et al., 2015). (E) Arabian Sea summer monsoon stack (Caley et al., 2011; Bolton et al., 2013). (F) Qinghai Lake westerlies climate index (An et al., 2012). The gray frames represent the prominent increase stages of alluvial aggradations. MIS, Marne Isotope Stage; LDG, Last Deglaciation; YD, Younger Dryas event.

distinguished during $\sim 10.5-12.0 \mathrm{ka}$ (Figures 5A,B). The good correspondence between forming ages of alluvial fans and those of glacial advances indicates that the latter controls the former's extension. Meanwhile, strong hydrographic discharge also probably promoted the stretches of alluvial fans and finished most valley fills of drainage basins; the hypothesis can be tested by the mass development of alluvial fans during the Last Deglaciation/Last Interglaciation periods. The melting glaciers yielded abundant high-load runoffs and transported surplus sediments, which boosted the aggradations toward the fan toes (Ou et al., 2014). The strengthened precipitation together with moderate glacier activities during the Late Interglaciation was probably somewhat responsible for the development of the alluvial fans, corresponding to the slight enhancement for the current probability density function (PDF) curves (Figures 5A,B). Previous studies provided enhanced evidence that the glacial advances occurred during the penultimate glacial cycle, MIS 3, Last Glacial Maximum (LGM), Late Glacial, and Holocene periods in the northeastern or southeastern mountain regions of the TP (Owen et al., 2003, 2006; Ou et al., 2014; Wang et al., 2014; He et al., 2016; Cui et al., 2021). The expansion of the extent of glaciers was affected by the change in precipitation, and the extent of glaciers during the MIS 3 was more extensive than that during the LGM (Owen et al., 2003; Cui et al., 2021). The alluvial fans originated from orographic outwash formed on the southern side of the Kunlun Mountains prior to $200 \mathrm{ka}$ (Owen et al., 2006) and 


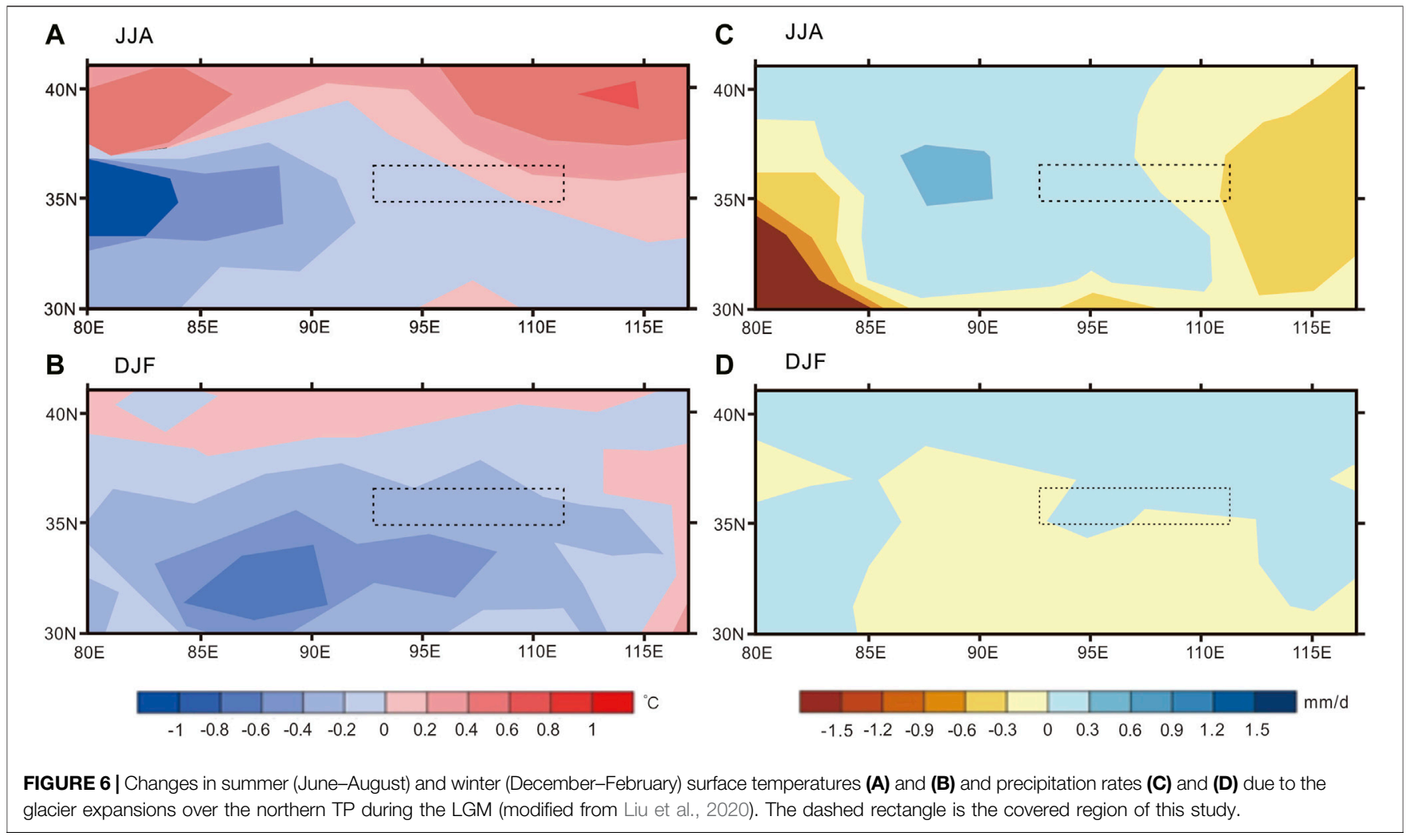

later frequently occurred in different paleoclimatic stages (Xu et al., 2010). Meanwhile, alluvial sequences in the eastern part of the NETP, such as Riyue Mountain and the Qinghainan Mountains, intensively formed during the MIS 3. This phenomenon is probably ascribed to the lower temperature and more abundant precipitation in this stage, including glacier activities combining the sufficient rainfall that were responsible for the alluvial geomorphic evolutions. Cui et al. (2021) argued that the coupling effect of lower temperature and increased precipitation on the NETP resulted in the expansion of the orographic glaciers during the MIS 3 rather than the LGM. A simulation result of the CAM4 climate model suggests that an expansion of glaciers would lead to a decrease in surface air temperatures during both the summer and winter over most regions of the $\mathrm{TP}$, and coupled with increased summer precipitation and increase in cold glacier meltwater supply, it would be in favor of alluvial advance and high lake levels (Liu et al., 2020).

\section{Paleoclimatic Implications for Glacier-Induced Alluvial Fans}

The NETP is situated in a sensitive arid and semi-arid zone between the ISM-controlled and the westerly-influenced regions of Asia, and the dominated atmospheric circulations were commonly altered from the interglacial to glacial periods (An et al., 2012). Thus, construction of the paleoclimate changes from the dynamics of the glacier and alluvial fan geomorphic processes is an intricate procedure. But, this allows us to distinguish the different climatic systems on the interglacial-to-glacial or interstadialto-stadial cycle timescales. The formation of the alluvial fans involved in the current study began since the late MIS 5 and ended during the early Holocene (Table 2 and Figure 5A). These results referred to various climatic stages, including the MIS 5, MIS 3, MIS 2, Last Deglaciation, and YD periods. Ramisch et al. (2016) suggested that the moisture status of the eastern Kunlun Mountain region is mainly dominated by the ISM and the mountains form the northern boundary of the monsoon system, which triggered orographic rainfall or snowfall. Cui et al. (2020) argued that the temperature drops ranged from -0.5 to $0.1^{\circ} \mathrm{C}$ with precipitation being $140 \sim$ $200 \%$ during the MIS 3 in the Kunlun Mountains. The lower temperature and high moisture were in favor of glacial advances (Cui et al., 2021), which contributed to abundant outwash supply and alluvial fill in the drainage basin. Recent studies have indicated that the glaciations of most regions of the TP were influenced by the ISM or the Asian monsoon during the MIS 5 and MIS 3, and the increased south Asian monsoon supplied more precipitation as snow at high altitudes (Owen et al., 2003; Xu et al., 2010; Stauch et al., 2017; Cui et al., 2021). However, a remarkable feature of the age distribution for alluvial fans indicates that the periods of Last Glaciation and Deglaciation are the main developing stages for the alluvial aggradations. The results are well consistent with the ages of the glacial advance (Figures 5A,B). An et al. (2012) found an antiphase relationship between the westerlies and the ASM for glacial millennial 
timescales in the Qinghai Lake catchment during the Last Glaciation. Li et al. (2020) argued that the Asian monsoon and the westerlies showed positive correlation on millennial timescales but anticorrelation during suborbital cycles. Therefore, we synthesized a record comparison between our alluvial age data with the proxies for ISM-dominated regions and the westerlies index from Qinghai Lake (Figures 5C-F). As shown in the figure, the alluvial age record closely matches that of glacier activities and the record of high lake levels on the southern TP, such as those of the Taro Co lake group (Figure $5 \mathrm{C}$ ). Alluvial aggradations are also consistent with the $\delta^{18} \mathrm{O}$ record of the stalagmites from the southwestern TP and the summer monsoon stack from the Arabian Sea (Figures 5D,E), suggesting the influence of the ISM during the MIS 5, MIS 3, and early Holocene. But the prominent increase in the alluvial ages during the Last Glaciation and Deglaciation showed more consistency with the westerlies index. Thus, we considered that strengthened westerlies combined with slight monsoon dominated the intensive glacial activities and alluvial aggradations in the drainage basin on the NETP during the Last Glaciation. This glacial expansion stage was verified using a simulation. The decrease in surface air temperatures and increase in precipitation rates during both the summer and winter boosted the orographic glacier activities (Figure 6), and they also showed inter-feedback to each other, especially the western mountains of the region. Subsequently, massive glaciers melted with the warming climate, finally facilitating a large scale of development for the alluvial fans during the Last Deglaciation.

\section{CONCLUSION}

Investigation on the climatically induced alluvial fans that cascaded from mountains in the semi-arid regions provides insight into the geomorphic and hydrographic processes driven by paleoclimatic fluctuations. We investigated a series of alluvial fans on the NETP region using the morphostratigraphic study and OSL dating. These alluvial sequences cascaded from the high piedmonts in the eastern Kunlun Mountains, Ela Mountain, the Qinghainan Mountains, and Riyue Mountain, ultimately filling the drainage basins or stretching into the arid sedimentary basins. Integrated analysis indicated that the alluvial geomorphic processes were related to the paleoclimate changes rather than the surface uplifts. These are basically composed of the coarse-to-fine, weak, and angular gravels and sandy lenticles, which occasionally contained boulders in specific layers. The OSL dating results showed that the alluvial fans had mainly developed during the late MIS 5, MIS3, and Last Glaciation and Deglaciation, little occurring during the early Holocene. The findings are firmly consistent with the orographic glacial advance periods in the northeastern and eastern regions of the TP. Considering that the alluvial fan is a production of downward outwash transportation according to previous studies, we argued that the dynamics of the alluvial fans and alluvial valley fills should be ascribed to the paleo-glacier activities during different climatic stages since the late Pleistocene. The comparisons of wet indexes between our age data and records from the ISMand westerly-dominated regions showed that both the climatic systems had coupling impacts on the glacial advances and subsequent alluvial aggradations on the supply of moisture in different paleoclimatic stages. The simulation also suggested that lower temperature and enhanced precipitation during the LGM resulted in the glacier expansion. This result matches with our data that indicate that the alluvial aggradations mainly occurred during the MIS 2 and the sequent postglacial stage.

\section{DATA AVAILABILITY STATEMENT}

The original contributions presented in the study are included in the article/Supplementary Material; further inquiries can be directed to the corresponding authors.

\section{ETHICS STATEMENT}

Written informed consent was obtained from the relevant individual(s) for the publication of any potentially identifiable images or data included in this article.

\section{AUTHOR CONTRIBUTIONS}

FA and SL designed the research. FA, BN, DG, and JZ performed the research. LC and XC made the figures and analyzed the data. FA and BQ wrote the manuscript. TC analyzed the OSL dating results with age models.

\section{FUNDING}

This study was supported by the Natural Science Foundation of Qinghai Province (Grant no. 2020-ZJ-727) and the China NSF (Grant no. 41961014).

\section{ACKNOWLEDGMENTS}

We thank Jun Li, Ping, Li, Jingyi Gao, Hongjun, Yu, Fuzhong Zhou, Zhiyong Ling, and Yixuan Wang for field assistance, discussion, and OSL dating. We would also like to thank the editor and the two reviewers who helped to improve the article.

\section{SUPPLEMENTARY MATERIAL}

The Supplementary Material for this article can be found online at: https:/www.frontiersin.org/articles/10.3389/feart.2021.702340/ full\#supplementary-material 


\section{REFERENCES}

Aitken, M. J. (1985). Thermoluminescence Dating. London: Academic Press.

Alivernini, M., Lai, Z., Frenzel, P., Fürstenberg, S., Wang, J., Guo, Y., et al. (2018). Late Quaternary lake Level Changes of Taro Co and Neighbouring Lakes, Southwestern Tibetan Plateau, Based on OSL Dating and Ostracod Analysis. Glob. Planet. Change 166, 1-18. doi:10.1016/j.gloplacha.2018.03.016

An, F., Lai, Z., Liu, X., Wang, Y., Chang, Q., Lu, B., et al. (2018a). Luminescence Chronology and Radiocarbon Reservoir Age Determination of Lacustrine Sediments from the Heihai Lake, NE Qinghai-Tibetan Plateau and its Paleoclimate Implications. J. Earth Sci. 29 (3), 695-706. doi:10.1007/s12583017-0972-9

An, F., Liu, X., Zhang, Q., Wang, Y., Chen, T., Yu, L., et al. (2018b). Drainage Geomorphic Evolution in Response to Paleoclimatic Changes since $12.8 \mathrm{Ka}$ in the Eastern Kunlun Mountains, NE Qinghai-Tibetan Plateau. Geomorphology 319, 117-132. doi:10.1016/j.geomorph.2018.07.016

An, F. Y., Chen, T. Y., Li, X. Z., Liu, X. J., Wang, Y. X., Chen, Z. Y., et al. (2021). Formation, Mechanism and Significance of Alluvial-Dammed Lakes in Golmud River Cathment, NE Qinghai-Tibetan Plateau. Earth Surf. Proc. Land.In Press.

An, Z., Colman, S. M., Zhou, W., Li, X., Brown, E. T., Jull, A. J. T., et al. (2012). Interplay between the Westerlies and Asian Monsoon Recorded in Lake Qinghai Sediments since 32 Ka. Sci. Rep. 2, 619-625. doi:10.1038/srep00619

Ashworth, P. (2006). Alluvial Fans: Geomorphology, Sedimentology, Dynamics Edited by Adrian Harvey, Anne Mather and Martin Stokes. Area 38 (2), 225-226. doi:10.1111/j.1475-4762.2006.690_5.x

Bolton, C. T., Chang, L., Clemens, S. C., Kodama, K., Ikehara, M., Medina-Elizalde, M., et al. (2013). A 500,000 Year Record of Indian Summer Monsoon Dynamics Recorded by Eastern Equatorial Indian Ocean Upper Water-Column Structure. Quat. Sci. Rev. 77 (77), 167-180. doi:10.1016/j.quascirev.2013.07.031

Bridgland, D. R. (2010). The Record from British Quaternary River Systems within the Context of Global Fluvial Archives. J. Quat. Sci. 25, 433-446. doi:10.1002/ jqs. 1383

Bureau of geology and mineral resources of Qinghai Province (1991). Regional Geology of Qinghai Province (Beijing, China: Geological Publishing House). (in Chinese with English abstract).

Cai, Y., Fung, I. Y., Edwards, R. L., An, Z., Cheng, H., Lee, J.-E., et al. (2015). Variability of Stalagmite-Inferred Indian Monsoon Precipitation over the Past 252,000 Y. Proc. Natl. Acad. Sci. USA 112 (112), 2954-2959. doi:10.1073/ pnas. 1424035112

Caley, T., Malaizé, B., Zaragosi, S., Rossignol, L., Bourget, J., Eynaud, F., et al. (2011). New Arabian Sea Records Help Decipher Orbital Timing of Indo-Asian Monsoon. Earth Planet. Sci. Lett. 308 (3-4), 433-444. doi:10.1016/j.epsl.2011.06.019

Chang, Q., Lai, Z., An, F., Wang, H., Lei, Y., and Han, F. (2017). Chronology for Terraces of the Nalinggele River in the north Qinghai-Tibet Plateau and Implications for Salt lake Resource Formation in the Qaidam Basin. Quat. Int. 430, 12-20. doi:10.1016/j.quaint.2016.02.022

Chen, P., Yu, Z., Czymzik, M., Aldahan, A., Wang, J., Yi, P., et al. (2021). Holocene Monsoon Dynamics at Kunlun Pass on the Northeastern Qinghai-Tibet Plateau. Sci. Total Environ. 771, 145369. doi:10.1016/j.scitotenv.2021.145369

Chen, Y., Aitchison, J. C., Zong, Y., and Li, S.-H. (2016). OSL Dating of Past lake Levels for a Large Dammed lake in Southern Tibet and Determination of Possible Controls on lake Evolution. Earth Surf. Process. Landforms 41 (11), 1467-1476. doi:10.1002/esp.3907

Chen, Y., Li, Y., Zhang, Y., Zhang, M., Zhang, J., Yi, C., et al. (2011). Late Quaternary Deposition and Incision Sequences of the Golmud River and Their Environmental Implications. Quat. Int. 236, 48-56. doi:10.1016/j.quaint.2010.05.028

Cui, H., Cao, G., Badingquiying, K., Chen, H., and Jiang, G. (2020). Climates since Late Quaternary Glacier Advances: Glacier-Climate Modeling in the Kunlun Pass Area, Burhan Budai Shan, Northeastern Tibetan Plateau. Quat. Int. 553, 53-59. doi:10.1016/j.quaint.2020.05.050Chen

Cui, H., Cao, G. C., Chen, K. L., Guo, H., and Jiang, G. (2021). A Review on the Reconstruction of Palaeoclimate by Glacial Landform in the Tibetan Plateau and Adjacent Mountains. J. Glaciology Geocryology 43 (1), 254-262.(in Chinese with English abstract)

Cui, Z. J., Wu, Y. Q., Ge, D. K., and Liu, G. N. (1999). Environmental Change of Kunlun Pass Area since Quaternary. Mar. Geology. Quat. Geology. 19, 53-62.(in Chinese with English abstract)
Gao, L., Wang, X., Yi, S., Vandenberghe, J., Gibling, M., Lu, H., et al. (2018). Episodic Sedimentary Evolution of an Alluvial Fan (Huangshui Catchment, NE Tibetan Plateau). Quaternary 1, 16. doi:10.3390/quat1020016

Guo, Q., Zhou, Z., and Wang, S. (2017). The Source, Flow Rates, and Hydrochemical Evolution of Groundwater in an Alluvial Fan of Qilian Mountain, Northwest China. Water 9, 912. doi:10.3390/w9120912

He, Z., He, Y., Zhang, Z., He, L., Qi, C., and Liu, J. (2016). OSL Dating of the Quaternary Glacial Sedimentary Sequences at Mt. Yulong, China. J. Glaciology Geocryology 38 (6), 1544-1552 doi:10.7522/j.issn.1000-0240-2016.0180in Chinese with English abstract)

Kapp, P., Pelletier, J. D., Rohrmann, A., Heermance, R., Russell, J., and Ding, L. (2011). Wind Erosion in the Qaidam basin, central Asia: Implications for Tectonics, Paleoclimate, and the Source of the Loess Plateau. Gsat 21, 4-10. doi:10.1130/GSATG99A.1

Lai, Z.-P., and Wintle, A. G. (2006). Locating the Boundary between the Pleistocene and the Holocene in Chinese Loess Using Luminescence. The Holocene 16 (6), 893-899. doi:10.1191/0959683606hol980rr

Lai, Z., and Brückner, H. (2008). Effects of Feldspar Contamination on Equivalent Dose and the Shape of Growth Curve for OSL of silt-sized Quartz Extracted from Chinese Loess. Geochronometria 30 (1), 49-53. doi:10.2478/v10003-008-0010-0

Lai, Z. (2010). Chronology and the Upper Dating Limit for Loess Samples from Luochuan Section in the Chinese Loess Plateau Using Quartz OSL SAR Protocol. J. Asian Earth Sci. 37 (2), 176-185. doi:10.1016/j.jseaes.2009.08.003 Lai, Z. P., Zöller, L., Fuchs, M., and Brückner, H. (2008). Alpha Efficiency Determination for OSL of Quartz Extracted from Chinese Loess. Radiat. Measurements 43 (2-6), 767-770. doi:10.1016/j.radmeas.2008.01.022

Lehmkuhl, F., Nottebaum, V., and Hülle, D. (2018). Aspects of Late Quaternary Geomorphological Development in the Khangai Mountains and the Gobi Altai Mountains (Mongolia). Geomorphology 312, 24-39. doi:10.1016/ j.geomorph.2018.03.029

Li, G., Yang, H., Stevens, T., Zhang, X., Zhang, H., Wei, H., et al. (2020a). Differential Ice Volume and Orbital Modulation of Quaternary Moisture Patterns between Central and East Asia. Earth Planet. Sci. Lett. 530, 115901 doi:10.1016/j.epsl.2019.115901

Li, G., Zhang, H., Liu, X., Yang, H., Wang, X., Zhang, X., et al. (2020b). Paleoclimatic Changes and Modulation of East Asian Summer Monsoon by High-Latitude Forcing over the Last 130,000 Years as Revealed by Independently Dated Loess-Paleosol Sequences on the NE Tibetan Plateau. Quat. Sci. Rev. 237, 106283. doi:10.1016/j.quascirev.2020.106283

Li, H., Van Der Woerd, J., Tapponnier, P., Klinger, Y., Qi, X., Yang, J., et al. (2005). Slip Rate on the Kunlun Fault at Hongshui Gou, and Recurrence Time of Great Events Comparable to 14/11/2001, Mw 7.9 Kokoxili Earthquake. Earth Planet. Sc. Lett. 237, 285-299.doi:10.1016/j.epsl.2005.05.041

Li, X., Liu, X., He, Y., Liu, W., Zhou, X., and Wang, Z. (2018). Summer Moisture Changes in the Lake Qinghai Area on the Northeastern Tibetan Plateau Recorded from a Meadow Section over the Past 8400 Yrs. Glob. Planet. Change 161, 1-9. doi:10.1016/j.gloplacha.2017.11.016

Li, Y., Han, L., Liu, X., Song, Y., and Wang, Y. (2021). Correlation and Anticorrelation of the Asian Summer Monsoon and Westerlies during the Holocene. Gondwana Res. 91, 112-120. doi:10.1016/j.gr.2020.12.013

Liu, B., Jin, H., Sun, L., Su, Z., Zhang, C., and Zhao, S. (2017). History of Moisture Change Derived from Slope Sediments of the Eastern Gonghe Basin (Northeastern Qinghai-Tibetan Plateau) during the Last 17 Ka. Geol. J. 52 (4), 583-593. doi:10.1002/gj.2795

Liu, W., Hu, K., Carling, P. A., Lai, Z., Cheng, T., and Xu, Y. (2018). The Establishment and Influence of Baimakou Paleo-Dam in an Upstream Reach of the Yangtze River, southeastern Margin of the Tibetan Plateau. Geomorphology 321, 167-173. doi:10.1016/j.geomorph.2018.08.028

Liu, W., Lai, Z., Hu, K., Ge, Y., Cui, P., Zhang, X., et al. (2015). Age and Extent of a Giant Glacial-Dammed lake at Yarlung Tsangpo Gorge in the Tibetan Plateau. Geomorphology 246, 370-376. doi:10.1016/j.geomorph.2015.06.034

Liu, X.-J., Lai, Z., Madsen, D., and Zeng, F. (2015). Last Deglacial and Holocene lake Level Variations of Qinghai Lake, north-eastern Qinghai-Tibetan Plateau. J. Quat. Sci. 30 (3), 245-257. doi:10.1002/jqs.2777

Liu, X.-J., Xiao, G., E, C., Li, X., Lai, Z., Yu, L., et al. (2017). Accumulation and Erosion of Aeolian Sediments in the Northeastern Qinghai-Tibetan Plateau and Implications for Provenance to the Chinese Loess Plateau. J. Asian Earth Sci. 135, 166-174. doi:10.1016/j.jseaes.2016.12.034 
Liu, X. J., Cong, L., Li, X. Z., Madsen, D., Wang, Y. X., Liu, Y. G., et al. (2020). Climate Conditions on the Tibetan Plateau during the Last Glacial Maximum and Implications for the Survival of Paleolithic Foragers. Front. Earth Sc-switz 8, 606051. doi:10.3389/feart.2020.606051

Liu, X., Lai, Z., Madsen, D., Yu, L., Liu, K., and Zhang, J. (2011). Lake Level Variations of Qinghai Lake in Northeastern Qinghai-Tibetan Plateau since 3.7 Ka Based on OSL Dating. Quat. Int. 236 (1), 57-64. doi:10.1016/ j.quaint.2010.08.009

Liu, X. Q., Dong, H. L., Rech, J. A., Matsumoto, R., Yang, B., and Wang, Y. B. (2008). Evolution of Chaka Salt Lake in NW China in Response to Climatic Change during the Latest Pleistocene-Holocene. J. Quat. Sci. 27, 867-879. doi:10.1016/j.quascirev.2007.12.006

Liu, X., Zhang, X., Lin, Y., Jin, L., and Chen, F. (2019). Strengthened Indian Summer Monsoon Brought More Rainfall to the Western Tibetan Plateau during the Early Holocene. Sci. Bull. 64, 1482-1485. doi:10.1016/ j.scib.2019.07.022

Murray, A. S., and Wintle, A. G. (2000). Luminescence Dating of Quartz Using an Improved Single-Aliquot Regenerative-Dose Protocol. Radiat. Meas. 32 (1), 53-57. doi:10.1016/S1350-4487(99)00253-X

Murray, A. S., and Wintle, A. G. (2003). The Single Aliquot Regenerative Dose Protocol: Potential for Improvements in Reliability. Radiat. Meas. 37 (4-5), 377-381. doi:10.1016/S1350-4487(03)00053-2

Ou, X., Lai, Z., Zhou, S., and Zeng, L. (2014). Timing of Glacier Fluctuations and Trigger Mechanisms in Eastern Qinghai-Tibetan Plateau during the Late Quaternary. Quat. Res. 81 (3), 464-475. doi:10.1016/j.yqres.2013.09.007

Owen, L. A., Finkel, R. C., Haizhou, M., and Barnard, P. L. (2006). Late Quaternary Landscape Evolution in the Kunlun Mountains and Qaidam Basin, Northern Tibet: A Framework for Examining the Links between Glaciation, lake Level Changes and Alluvial Fan Formation. Quat. Int. 154-155, 73-86. doi:10.1016/ j.quaint.2006.02.008

Owen, L. A., Finkel, R. C., Haizhou, M., Spencer, J. Q., Derbyshire, E., Barnard, P. L., et al. (2003). Timing and Style of Late Quaternary Glaciation in Northeastern Tibet. Geo. Soc. Am. Bull. 115 (11), 1356-1364. doi:10.1130/B25314.1

Prescott, J., and Hutton, J. T. (1994). Cosmic Ray Contributions To Dose Rates For Luminescence and ESR Dating: Large Depths and Long-Term Time Variations. Radiat Meas 23, 497-500. doi:10.1016/1350-4487(94)90086-8

Ramisch, A., Lockot, G., Haberzettl, T., Hartmann, K., Kuhn, G., Lehmkuhl, F., et al. (2016). A Persistent Northern Boundary of Indian Summer Monsoon Precipitation over Central Asia during the Holocene. Sci. Rep. 6, 25791. doi:10.1038/srep25791

Ritter, J. B., Miller, J. R., Enzel, Y., and Wells, S. G. (1995). Reconciling the Roles of Tectonism and Climate in Quaternary Alluvial Fan Evolution. Geol 23, 245-248. doi:10.1130/0091-7613(1995)0232.3.CO10.1130/0091-7613(1995) $023<0245$ :rtrota $>2.3$. co; 22

Stauch, G., Schulte, P., Ramisch, A., Hartmann, K., Hülle, D., Lockot, G., et al. (2017). Landscape and Climate on the Northern Tibetan Plateau during the Late Quaternary. Geomorphology 286, 78-92. doi:10.1016/j.geomorph.2017.03.008

Tao, Y., Xiong, J., Zhang, H., Chang, H., and Li, L. (2020). Climate-driven Formation of Fluvial Terraces across the Tibetan Plateau since $200 \mathrm{Ka}$ : A Review. Quat. Sci. Rev. 237, 106303. doi:10.1016/j.quascirev.2020.106303

Van Der Woerd, J., Tapponnier, P., Ryerson, F. J., Meriaux, A.-S., Meyer, B., Gaudemer, Y., et al. (2002). Uniform Postglacial Slip-Rate along the central 600 $\mathrm{Km}$ of the Kunlun Fault (Tibet), from 26Al, 10Be, and 14C Dating of Riser Offsets, and Climatic Origin of the Regional Morphology. Geophys. J. Int. 148, 356-388. doi:10.1046/j.1365-246x.2002.01556.x

Vandenberghe, J. (1995). Timescales, Climate and River Development. Quat. Sci. Rev. 14, 631-638. doi:10.1016/0277-3791(95)00043-O
Wang, A., Smith, J. A., Wang, G., Zhang, K., Xiang, S., and Liu, D. (2009). Late Quaternary River Terrace Sequences in the Eastern Kunlun Range, Northern Tibet: a Combined Record of Climatic Change and Surface Uplift. J. Asian Earth Sci. 34, 532-543. doi:10.1016/j.jseaes.2008.09.003

Wang, H., Cui, P., Liu, D., Liu, W., Bazai, N. A., Wang, J., et al. (2019). Evolution of a Landslide-Dammed lake on the southeastern Tibetan Plateau and its Influence on River Longitudinal Profiles. Geomorphology 343, 15-32. doi:10.1016/j.geomorph.2019.06.023

Wang, J., Kassab, C., Harbor, J. M., Caffee, M. W., Cui, H., and Zhang, G. (2013). Cosmogenic Nuclide Constraints on Late Quaternary Glacial Chronology on the Dalijia Shan, Northeastern Tibetan Plateau. Quat. Res. 79, 439-451. doi:10.1016/j.yqres.2013.01.004

Xu, L., Ou, X., Lai, Z., Zhou, S., Wang, J., and Fu, Y. (2010). Timing and Style of Late Pleistocene Glaciation in the Queer Shan, Northern Hengduan Mountains in the Eastern Tibetan Plateau. J. Quat. Sci. 25 (6), 957-966. doi:10.1002/ jqs.1379

Yu, J., Gao, C., Cheng, A., Liu, Y., Zhang, L., and He, X. (2013). Geomorphic, Hydroclimatic and Hydrothermal Controls on the Formation of Lithium Brine Deposits in the Qaidam Basin, Northern Tibetan Plateau, China. Ore Geology. Rev. 50, 171-183. doi:10.1016/j.oregeorev.2012.11.001

Yuan, D.-Y., Champagnac, J.-D., Ge, W.-P., Molnar, P., Zhang, P.-Z., Zheng, W.-J., et al. (2011). Late Quaternary Right-Lateral Slip Rates of Faults Adjacent to the Lake Qinghai, Northeastern Margin of the Tibetan Plateau. Geol. Soc. America Bull. 123 (9-10), 2016-2030. doi:10.1130/B30315.1

Zhang, H.-P., Craddock, W. H., Lease, R. O., Wang, W.-t., Yuan, D.-Y., Zhang, P.Z., et al. (2012). Magnetostratigraphy of the Neogene Chaka Basin and its Implications for Mountain Building Processes in the north-eastern Tibetan Plateau. Basin Res. 24 (1), 31-50. doi:10.1111/j.1365-2117.2011.00512.x

Zhang, H.-P., Craddock, W. H., Lease, R. O., Wang, W.-t., Yuan, D.-Y., Zhang, P.Z., et al. (2011). Magnetostratigraphy of the Neogene Chaka basin and its Implications for Mountain Building Processes in the north-eastern Tibetan Plateau. Basin Res. 24, 31-50. doi:10.1111/j.1365-2117.2011.00512.x

Zhang, H., and Lü, Y. (2014). Geomorphometric Features of the Alluvial Fans Around the Chaka-Qinghai Lake in the Northeastern Tibetan Plateau. J. Earth Sci. 25 (4), 109-116. doi:10.1007/s12583-014-0404-Z

Zhang, W., Mischke, S., Zhang, C., Gao, D., and Fan, R. (2013). Ostracod Distribution and Habitat Relationships in the Kunlun Mountains, Northern Tibetan Plateau. Quat. Int. 313-314 (10), 38-46. doi:10.1016/ j.quaint.2013.06.020

Conflict of Interest: The authors declare that the research was conducted in the absence of any commercial or financial relationships that could be construed as a potential conflict of interest.

Publisher's Note: All claims expressed in this article are solely those of the authors and do not necessarily represent those of their affiliated organizations, or those of the publisher, the editors and the reviewers. Any product that may be evaluated in this article, or claim that may be made by its manufacturer, is not guaranteed or endorsed by the publisher.

Copyright (c) 2021 An, BadingQiuying, Li, Gao, Chen, Cong, Zhang and Cheng. This is an open-access article distributed under the terms of the Creative Commons Attribution License (CC BY). The use, distribution or reproduction in other forums is permitted, provided the original author(s) and the copyright owner(s) are credited and that the original publication in this journal is cited, in accordance with accepted academic practice. No use, distribution or reproduction is permitted which does not comply with these terms. 